\title{
IMPLEMENTASI PEMBELAJARAN PADA LABORATORIUM GEOGRAFI BERBANTUAN MEDIA PETA PEMANFAATAN LAHAN GAMBUT DI SMA NEGERI 3 PONTIANAK
}

\author{
Nur Meily Adlika $^{1)}$, Budiman Tampubolon ${ }^{2)}$, Edwin Mirzachaerulsyah ${ }^{3)}$, Nunung Juniarti ${ }^{4)}$ \\ ${ }^{2)}$ UNTAN, Pontianak, Indonesia \\ E-mail:nurmeilyadlika@fkip.untan.ac.id
}

\begin{abstract}
Abstrak. Artikel ini merupakan penelitian yang dilaksanakan pada tahun pelajaran 2018/2019. Peneliitian ini bertujuan untuk mengetahui pembelajaran geografi pada laboratorium geografi dan untuk mengetahui penggunaan peta pemanfaatan lahan gambut di SMA Negeri 3 Pontianak. Penelitian ini merupakan penelitian deskriptif dengan pendekatan kualitatif. Teknik pengumpulan data menggunakan wawancara, observasi, dan dokumentasi. Analisis data menggunakan pengumpulan data, reduksi data, penyajian data, dan kesimpulan. Teknik pemeriksaan keabsahan data menggunakan trianguasi. Hasil penelitian menunjukkan bahwa 1) Pembelajaran pada laboratorium geografi berlangsung selama kurang lebih 2x45menit atau 2 jam pelajaran dengan pendekatan yang digunakan adalah project based learning. Pembelajaran berbasis proyek menekankan pada proses dan hasil yang telah dicapai proses tersebut meliputi perencanaan, pelaksanaan dan presentasi hasil praktikum serta tata tertib terhadap kaidah-kaidah penggunaan laboratorium. 2) Peserta didik menggunakan dua peta yakni peta sebaran lahan gambut dan peta penggunaan lahan untuk membedakan daerah yang berpotensi sebagai area konservasi dan area yang dapat dimanfaatkan oleh masyarakat sebagai kawasan pertanian dan peternakan.
\end{abstract}

Kata Kunci: Implementasi, Pembelajaran, Laboratorium, Geografi, Media, Peta

\section{Pendahuluan}

Pendidikan merupakan jaminan utama untuk membentuk kualitas sumber daya manusia suatu bangsa sehingga kualitas pendidikan merupakan sesuatu yang tidak boleh diabaikan senada dengan hal tersebut Undang-Undang Nomor 20 Tahun 2003 tentang Sistem Pendidikan Nasional menyatakan bahwa pendidikan merupakan usaha sadar dan terencana untuk mewujudkan suasana belajar dan proses pembelajaran agar peserta didik secara aktif mengembangkan potensi dirinya untuk memiliki kekuatan spiritual keagamaan, pengendalian diri, kepribadian, kecerdasan, akhlak mulia, serta keterampilan yang diperlukan dirinya, masyarakat, bangsa dan negara.

Suatu sistem pendidikan dikatakan berkualitas jika ketersediaan sarana dan prasarana penunjanya juga berkualitas sehingga akan tercipta proses pembelajaran yang menarik dan menantang. Proses pendidikan yang berkualitas akan membuahkan hasil pendidikan yang berkualitas pula dengan demikian akan makin meningkatkan kualitas kehidupan bangsa (Harsanto 2011: 9). Ketersediaan sarana prasarana yang berkualitas seperti media pembelajaran, laboratorium dan alat pembelajaran merupakan cara yang dapat ditempuh untuk meningkatkan kualitas proses pembelajaran.

Senada dengan hal tersebut Sumarni (2012: 3) juga menyatakan bahwa ada tiga faktor yang sangat berpengaruh terhadap keberhasilan pendidikan, yaitu: 1) perangkat keras (hardware), yang meliputi ruang belajar, peralatan praktik, laboratorium, dan perpustakaan; 2) perangkat lunak (software), yang meliputi kurikulum, program pembelajaran, manajemen sekolah, sistem pembelajaran 3) perangkat pikir (brainware), yaitu pendidik, peserta didik dan orang-orang yang terkait dalam proses tersebut.

Mustaji (2009) mengemukakan bahwa Laboratorium ialah tempat untuk melatih siswa dalam hal keterampilan melakukan praktek, demonstrasi, percobaan, penelitian, dan pengembangan ilmu pengetahuan.Laboratorium memiliki peranan penting dalam kaitanya sebagai sarana penunjang proses pembelajaran. Penggunaan laboratorium akan memaksimalkan dan meningkatkan kualitas sarana dan prasarana pembelajaran. Penggunaan laboratorium merupakan salah satu faktor yang memberikan andil cukup besar terhadap keberhasilan pembelajaran termasuk geografi. 
Menurut Ikatan Geografi Indonesia (IGI) dalam Budiyono (2003:3), Geografi adalah ilmu yang mempelajari persamaan dan perbedaan fenomena geosfer dengan sudut pandang kelingkungan dan kewilayahan dalam konteks keruangan.Fenomena geosfer yang dimaksud adalah gejalagejala yang ada dipermukaaan bumi baik lingkungan alam maupun makhluk hidupnya termasuk manusia. Berdasarkan Permendikbud nomor 69 tahun 2013 tentang Kerangka Dasar dan Struktur Kurikulum Sekolah Menengah/Madrasah Aliyah pengertian Geografi adalah ilmu yang mempelajari hubungan kausal berbagai gejala dan peristiwa yang terjadi di muka bumi, baik fisik maupun yang menyangkut makhluk hidup beserta permasalahannya melalui pendekatan keruangan, ekologi, dan regional. Hasil kajian geografi diarahkan untuk kepentingan program, proses, dan keberhasilan pembangunan.Proses mendeskripsikan, memahami, mengidentifikasi, mengevaluasi, dan mengatasi masalah pembangunan, geografi dibantu oleh sejumlah teknologi seperti penginderaan jauh, peta, dan Sistem Informasi Geografis (SIG).

Geografi merupakan salah satu mata pelajaran yang membutuhkan laboratorium dalam proses pembelajaran. Penggunaan laboratorium geografi yang efektif diharapkan mampu meningkatkan motivasi belajar siswa, ketrampilan siswa dalam menggunakan alat-alat praktikum, serta hasil belajar yang memuaskan. Dalam penelitian ini alat praktikum yang akan digunakan adalah media berupa peta. Penggunaan peta pada laboratorium geografi merupakan bagian dari inovasi pembelajaran untuk memudahkan peserta didik melakukan pengamatan dan membuat analisis mengenai kondisi lingkungan.Dalam hal ini peta yang digunakan keadaan lahan gambut dan konservasi keanekaragaman hayati.

Lahan gambut merupakan suatu ekosistem spesifik yang selalu tergenang air (waterlogged) memiliki multi fungsi antara lain fungsi ekonomi, pengatur hidrologi, lingkungan, budaya, dan keragaman hayati. Lahan gambut umumnya disusun oleh sisa vegetasi yang terakumulasi dalam waktu yang cukup lama dan membentuk tanah gambut.Tanah gambut bersifat rentan perubahan (fragile), relatif kurang subur, dan kering tak dapat balik (irreversible). Menurut BBSDLP (2012) lahan gambut dapat didefinisikan sebagai lahan yang terbentuk dari penumpukan/akumulasi sisa-sisa tumbuhan yang sebagian belum melapuk, memiliki ketebalan $50 \mathrm{~cm}$ atau lebih dan mengandung C-organik sekurang-kurangnya $12 \%$ (berat kering). Menurut Soil Survey Staff (2010) definisi tanah gambut atau Histosol adalah tanah yang mempunyai lapisan bahan organik dengan ketebalan $>40 \mathrm{~cm}$ dengan berat isi (BD) $>0,1 \mathrm{~g} / \mathrm{cm} 3$, atau mempunyai ketebalan $>60 \mathrm{~cm}$ apabila BD-nya.

Sifat fisik tanah gambut lainnya adalah sifat mengering tidak balik. Gambutyang telah mengering, dengan kadar air $<100 \%$ (berdasarkan berat), tidak biasmenyerap air lagi kalau dibasahi. Gambut yang mengering ini sifatnya sama dengan kayu kering yang mudah hanyut dibawa aliran air dan mudah terbakar dalam keadaan kering (Widjaja-Adhi, 1988). Gambut yang terbakar menghasilkan energi panas yang lebih besar dari kayu/arang terbakar.Gambut yang terbakar juga sulit dipadamkan dan apinya bisa merambat di bawah permukaan sehingga kebakaran lahan bisa meluas tidak terkendali (Agus \& Subiksa, 2008).

Penggunaan peta pada laboratorium geografi merupakan bagian dari inovasi pembelajaran untuk memudahkan peserta didik melakukan pengamatan dan membuat analisis mengenai kondisi lingkungan dalam hal ini keadaan lahan gambut dan konservasi keanekaragman hayati.Pemanfaatan peta sebagai sarana interaktif dinilai relevan dengan kondisi saat ini dimana pemerolehan informasi dan analisis kawasan menjadi prioritas pemerintah dalam upaya merestorasi lahan gambut. Akurasi dalam peta juga dapat terus disempurnakan sehingga nantinya data-data dalam peta akan terus dapat diperbaharui dan dapat dimanfaatkan untuk melakukan penelitian lebih jauh.

\section{METODE}

Penelitian ini menggunakan metode peneitian kualitatif. Populasi dalam penelitian ini adalah seluruh siswa kelas $\mathrm{X}$ IPS SMA Negeri 3 Pontianak sebanyak siswa. Sampel ditentukan dengan menggunakan teknik simple random sampling yang menghasilkan satu kelas subjek penelitian yaitu kelas X IPS 2.

\section{ANALISIS DATA}

Analisis data pada penelitian ini yaitu pengumpulan data, reduksi data, penyajian data dan kesimpulan. Teknik pemeriksaan keabsahan data menggunakan trianguasi.

\section{HAIL DAN PEMBAHASAN}

1. Pembelajaran Geografi pada Laboratorium

Laboratorium geografi milik SMA Negeri 3 Kota Pontianak belum memiliki fasilitas yang memadai seperti kelengkapan alat praktikum dan sarana prasarana penunjang lainnya seperti material, alat ukur dan alat praktik sehingga dalam proses pelaksanaan pembelajaran peserta didik hanya sebatas menggunakan alat dan bahan yang dibawa sendiri.

Pembelajaran pada laboratorium geografi berlangsung selama kurang lebih $2 \times 45$ menit atau 2 jam pelajaran dengan pendekatan yang digunakan adalah project based learning secara umum proses pembelajaran akan dijabarkan sebagai berikut:

a. Persiapan

1) Peserta didik menyiapkan alat dan bahan untuk praktikum.

2) Peserta didik mengajukan permohonan izin menggunakan laboratorium geografi milik SMA Negeri 3 Kota Pontianak.

3) Peserta didik membentuk kelompok belajar

b. Pelaksanaan

1) Peserta didik diberi arahan tentang tata tertib penggunaan laboratorium oleh pranata laboratorium.

2) Peserta didik menggunakan pakaian praktik laboratorium. 
3) Peserta didik mempersiapkan alat dan bahan untuk praktikum

4) Peserta didik mengamati, melakukan eksperimen dan menampilkan hasilnya

5) Peserta didik mempresentasikan hasil temuan.

c. Evaluasi

1) Guru memberikan tugas berupa analisa produk yang telah dikerjakan dalam hal ini adalah pengamatan peta potensi lahan gambut.

2) Guru memberikan tugas berupa laporan hasil praktikum.

2. Penggunaan Peta Pemanfaatan Lahan Gambut

Peta berguna sebagai sarana untuk mengamati, mengukur dan mengoptimalkan sebaran analisa data lapangan. Media pembelajaran peta berguna untuk memberikan informasi kepada peserta didik terkait pengembangan data dan informasi spasial dan kawasan.Dalam penelitian ini peneliti menggunakan peta pemanfaatan potensi lahan gambut sebagai sarana praktikum geografi. Peta yang digunakan berupa peta sebaran lahan gambut di Kabupaten Kubu Raya dan yang kedua adalah peta penggunaan lahan di Kabupaten Kubu Raya.

Media sejatinya merupakan alat bantu visual yang mampu merangsang peserta didik untuk mengembangkan imajinasi dan nalarnya sehingga media berperan penting sebagai alat penyampaian informasi media peta yang visualisasinya telah disesuaikan dengan analisis kebutuhan pembelajaran akan dijabarkan dan ditelaah lebih rinci oleh peserta didik. Fokus pembelajaran dalam praktikum yang akan dicapai antara lain:

a. Menganalisis sebaran lahan gambut di Kabupaten Kubu Raya khususnya kawasan yang memiliki potensi pemanfaatan dan konservasi keanekaragaman hayati.

b. Menganalisis bentuk-bentuk pemanfaatan lahan gambut yang sesuai dengan kontur wilayah.

c. Menganalisis bentuk-bentuk konservasi keanekaragaman hayati yang dapat dikembangkan.

Sehingga peserta didik dapat memperoleh pengetahuan kognitif berupa analisis pemanfaatan wilayah, AMDAL dan potensi keanekaragaman hayati yang dapat dijaga. Setelah dilakukan proses praktikum diperoleh hasil pengamatan berupa peserta didik dapat menentukan daerah-daerah mana yang berpotensi dijadikan kawasan pengembangan pariwisata, pertanian dan peternakan di kawasan Kabupaten Kubu Raya khususnya di areal kawasan gambut Kecamatan Rasau Jaya.

Guru sebagai fasilitator dalam hal ini Yumiri, S.Pd memberikan masukan berupa pemanfaatan potensi pertanian dapat dilakukan dengan mengolah tanah gambut terlebih dahulu agar kadar asam nya rendah dan unsur hara meningkat. Produk-produk pertanian juga dapat dihasilkan dengan maksimal apabila dilakukan ujicoba pemupukan dari pupuk kandang sampai pupuk kimia.

Peserta didik menggunakan dua peta tersebut untuk membedakan daerah yang berpotensi sebagai area konservasi dan area yang dapat dimanfaatkan oleh masyarakat sebagai kawasan pertanian dan peternakan.

\section{KESIMPULAN}

1. Pembelajaran pada laboratorium geografi berlangsung selama kurang lebih 2x45menit atau 2 jam pelajaran dengan pendekatan yang digunakan adalah project based learning. Pembelajaran berbasis proyek menekankan pada proses dan hasil yang telah dicapai proses tersebut meliputi perencanaan, pelaksanaan dan presentasi hasil praktikum serta tata tertib terhadap kaidah-kaidah penggunaan laboratorium.

2. Peserta didik menggunakan dua peta tersebut untuk membedakan daerah yang berpotensi sebagai area konservasi dan area yang dapat dimanfaatkan oleh masyarakat sebagai kawasan pertanian dan peternakan

\section{REFERENCES}

Agus, F. dan I.G. M. Subiksa. 2008. Lahan Gambut: Potensi untuk Pertanian dan Aspek Lingkungan. Balai Penelitian Tanah dan World Agroforestry Centre (ICRAF), Bogor, Indonesia.

Badan Penelitian dan Pengembangan Pertanian. 2012. Pengertian, Istilah, Definisi, dan Sifat Tanah Gambut. Badan Penelitian dan Pengembangan Pertanian, Kementerian Pertanian.

Budiyono.2003. Metodologi Penelitian Pendidikan. Surakarta: UNS Press.

Mustaji. 2009. "Pengembangan berpikir kritis dan kreatif" dalam Beyer: Critical Thinking. Social Education, 45 (4).

Radno Harsanto. 2011. Pengelolaan Kelas yang Dinamis. Yogyakarta: Penerbit Kanisius.

Republik Indonesia. 2003. Undang-undang Republik Indonesia No. 20 Tahun 2003 tentang Sistem Pendidikan Nasional. Lembaran Negara RI Tahun 2003. Sekretariat Negara. Jakarta.

Republik Indonesia. 2013. Permendikbud nomor 69 tahun 2013 tentang Kerangka Dasar dan Struktur Kurikulum Sekolah Menengah/Madrasah Aliyah.

Sumarmi. 2012. Model-Model Pembelajaran Geografi. Malang: Aditya Media Publishing.

Soil Survey Staff. 2010. Keys to Soil Taxonomy. Eleventh Edition. United States Departement of Agriculture. Natural Resources Conservation Services.

Widjaja-Adhi, I P.G. 1988. Physical and chemical characteristic of peat soil of Indonesia. Ind. Agric. Res. Dev. J. 10:59-64. 